\title{
SOLUTE EFFECTS OF BORON AND ZIRCONIUM ON MICROPOROSITY
}

\author{
K. C. Antony
}

Technology Division, Stellite $R$ \& D Department Cabot Corporation, Kokomo, Indiana

\author{
J. F. Radavich
}

Materials Engineering

Purdue University, Lafayette, Indiana

\author{
ABSTRACT
}

It is generally agreed that solutes which tend to increase the solidification range of an alloy significantly affect microporosity in castings. Binary phase diagrams suggest that boron and zirconium - solutes which are traditionally added in small amounts to cast nickel basc alloys -- might significantly affect the solidification range, hence microporosity, of cast nickel-base superalloys. The effects of these suspect solutes on the solidification range and mechanical properties of a highly alloyed nickel-base superalloy were measured and correlated with the microporosity levels in production castings produced from these alloys. Based on the results of this study it would seem that: boron content should be maintained at the traditional $0.01 \%$ leve1; and zirconium should be eliminated from nickel-base alloys used for microporosity-limited applications. 


\section{Introduction}

Microporosity in conventional castings is a common microdefect emanating from gas exsolution and/or solidification shrinkage. Gas-induced microporosity is not normally regarded as a problem with nickel-base superalloys because of their high "reactive" element content but shrinkage-induced microporosity is virtually inevitable with nickel-base superalloys.

Shrinkage-induced microporosity is thought to occur when the local liquid metal pressure $\left(\mathrm{P}_{1}\right)$ ceases to be positive during the latter stages of solidification. Liquid metal pressures during the initial stages of solidification are generally high and correspond to a first approximation to the sum of the ambient pressure $\left(P_{a}\right)$ and the metallostatic pressure $\left(P_{h}\right)$, i.e. $P_{1}=P_{a}+P_{h}$. As solidification progresses, $P_{1}$ continually decreases due to the pressure drop $(\Delta P)$ associated with feeding liquid metal through a narrow flow channel. $(1,2,3)$

Nickel-base superalloys are particularly susceptible to shrinkage-induced microporosity since most nickel-base superalloys are cast in vacuum; therefore, initial liquid metal pressures do not benefit from ambient pressure. In addition, nickel-base superalloys tend to be "mushy freezing" and, to accommodate solidification shrinkage, feeding must be accomplished through narrow interdendritic channels causing relatively large pressure drops during the latter stages of solidification.

Several attempts have been made to calculate $\Delta \mathrm{P}$ based on fundamental fluid flow and heat transfer considerations. Proposed solutions vary, but they generally indicate the pressure drop is least when the local solidification time $\left(t_{f}\right)$ is greatest and/or when the alloy solidification range $(\Delta T)$, i.e. difference between alloy liquidus and solidus temperatures, is least. To a first approximation, the relationship between pressure drop, solidification range and solidification time can be expressed as:

$$
\Delta \mathrm{P}=\frac{\mathrm{k}(\Delta \mathrm{T})^{2}}{\mathrm{t}_{\mathrm{f}}}
$$

where $k$ is a constant of proportionality.

Indeed, many foundry "tricks of the trade" to minimize microporosity in nickel-base superalloy castings simply involve increasing ambient pressure (quick release from vacuum, hot top, etc.) or increasing local solidification time (high mold temperatures, low thermal conductivity shell materials, etc.). However, very few if any practical attempts have been made to minimize microporosity by manipulating the alloy solidification range.

"Melting ranges" for cast nickel-base superalloys reportedly vary between $27^{\circ} \mathrm{C}$ (IN $713 \mathrm{C}$ ) to $72^{\circ} \mathrm{C}$ (IN 100) with an average of about $42^{\circ} \mathrm{C}$. Reducing the melting or solidification range by as 1 ittle as $5^{\circ} \mathrm{C}$ could conceivably reduce microporosity by as much as $25 \% !(4,5)$

The solidification range for unalloyed nickel is nil but increases with alloying additions up to the maximum solid solubility of the alloying additions. Alloying additions in excess of the solid solubility limit reduce the solidification range to $\mathrm{nil}$ at the eutectic." The effect of individual alloy additions on the solidification range of a nickel-base superalloy can be estimated, albeit imprecisely, from binary phase diagrams. Consider for example the nicke1-aluminum system illustrated in Fig. 1. The maximum solubility of aluminum in nickel is approximately $9.6 \%$ (by weight). The equilibrium solidus and Iiquidus temperatures at $9.6 \%$ aluminum are approximately $1402^{\circ} \mathrm{C}$ and $1385^{\circ} \mathrm{C}$, respectively, corresponding to a solidification range of about $17^{\circ} \mathrm{C}$ at $9.6 \% \mathrm{~A} 1$, i.e. $\sim 2^{\circ} \mathrm{C}$ per weight percent aluminum. Since aluminum is seldom added to nickel-base superalloys in amounts greater than 


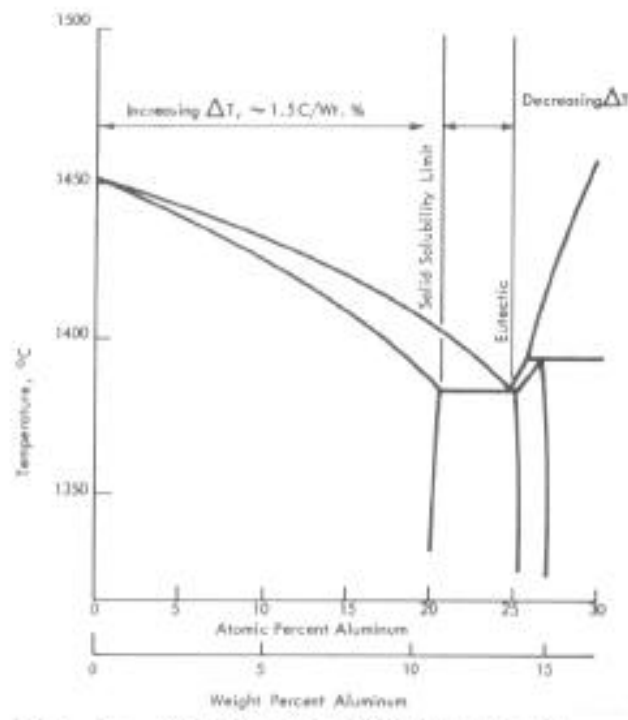

Fig. 1. Nicke1-rich portion of the nicke1-aluminum phase diagram.

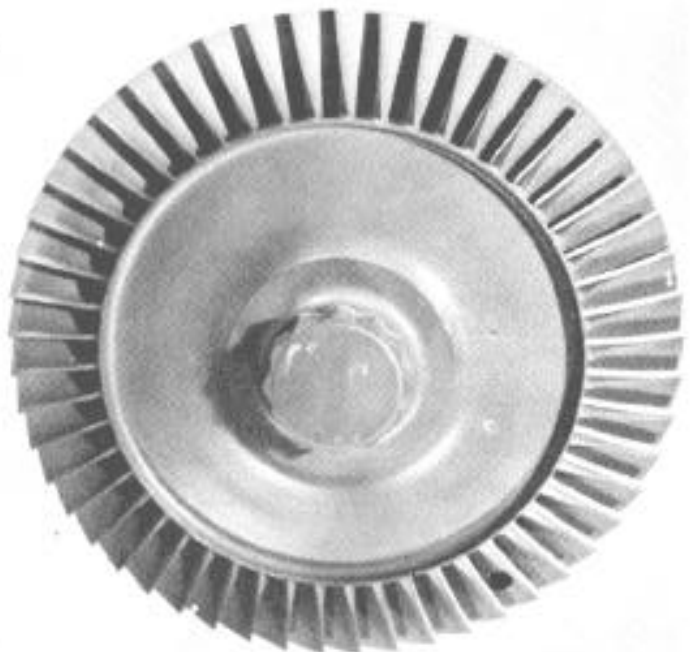

Fig. 2. Gas turbine integral whee1 investment casting.

the solid solubility limit, it is reasonable to estimate that aluminum wil increase the solidification range of nickel-base superalloys by $-2^{\circ} \mathrm{C}$ per weight percent aluminum. (6)

Obviously, major modifications in aluminum content are required to significanty affect the solidiftcation range of nickel-base superalloys. Solutes such as boron and zirconitum could have a much greater effect on the solidification range of nickel-base superalloys.

The maximum solid solubility of boron in nickel is $0.015 \%$ by weight. Boron additions less than the solubility 11 mit moderately affect the binary liquidus temperatures while significantly lowering binary solidus temperatures. The solidification range at $0.015 \%$ boron is greater than $300^{\circ} \mathrm{C}$ Indicating that boron could potentially increase the solidification range of nickel-base superalloys by as much as $2500^{\circ} \mathrm{C}$ per weight percent boron. The solid solubility of boron in actual nickel-base superalloys must, however, be considerably less than $0.015 \%$ since the solidification range of actual nickel-base superalloys containing as much as $0.015 \%$ boron is only of the order of 40 to $45^{\circ} \mathrm{C}$. Nevertheless, boron remains an interesting solute with respect to its effects on the solidification range and microporosity.

Zirconlum is surprisingly similar to boron with respect to its effect on binary alloy solidification ranges. Zirconium in amounts less than the binary solid solubility 1 init $(0.9 \%)$ moderately affects 1iquidus temperatures but significantly lowers solidus temperatures. The solidification range at $0.9 \%$ zirconium is $-260^{\circ} \mathrm{C}$ indicating that zirconium could increase the solidification range of nickel-base superalloys by as much as $280^{\circ} \mathrm{C}$ per weight percent zirconium.

While boron and zirconium are normally added to nickel-base superalloys in amount s ranging between $0.005 \%$ to $0.020 \%$ and $0.05 \%$ to $0.15 \%$, respectively, their effects on solidification range - even in trace amounts - are potentially significant. 


\section{Experimental}

The actual effects of trace additions of boron and zirconium on the solidification range and microporosity level in nickel-base superalloys were experimentally assessed by producing castings from a nickel-base superalloy in which boron and zirconium were intentionally varied. The base alloy selected for study was a versatile $\mathrm{Ni}-10 \mathrm{Co}-9 \mathrm{Cr}-9 \mathrm{~W}-5.5 \mathrm{~A} 1-3.5 \mathrm{Ta}-1.5 \mathrm{Mo}-1.5 \mathrm{Ti}$ superalloy developed by Ford Motor Company especially for gas turbine integra1 wheel applications. Experimental modifications of the base alloy were prepared by vacuum induction melting a master heat to which controlled amounts of zirconium and/or boron were subsequently added. The casting practices used to produce the castings were representative of the "state of the art" and the cast wheel configuration is shown in Fig. 2 .

The castings were sectioned and examined using conventional metallographic techniques. Microporosity levels in critical disc/rim sections were carefully examined at $50 \mathrm{x}$ to precisely identify the most porous area in that section. The areal percentage of microporosity was measured directly from 3-1/2" $\times$ 4-1/2" photographs of the selected areas. In effect, the microporosity measurements in this investigation properly refer to the microporosity level in the worst 0.0063 square inch field of view.

Microstructural studies were carried out on samples which were electropolished only as well as in the etched condition. Structural features were recorded with a JEOLCO SEM and phases in situ were chemically analyzed with a PGT 1000 nondispersive analyzer. X-ray diffraction studies of extracted residues were carried out.

The solidification range of each alloy was measured using a DuPont Model 900 Differential Thermal Analyzer (DTA) equipped with an unalloyed nickel reference cell. The DTA samples, in the form of filings, were taken directly from the hub sections of the castings. The DTA samples were heated at $\sim 15^{\circ} \mathrm{C}$ per minute in a flowing ( 45 liters per hour) argon atmosphere to a maximum temperature of $\sim 1500^{\circ} \mathrm{C}$ and free-cooled back to room temperature. A typical DTA thermogram for base alloy remelt bar is illustrated in Fig. 3 .

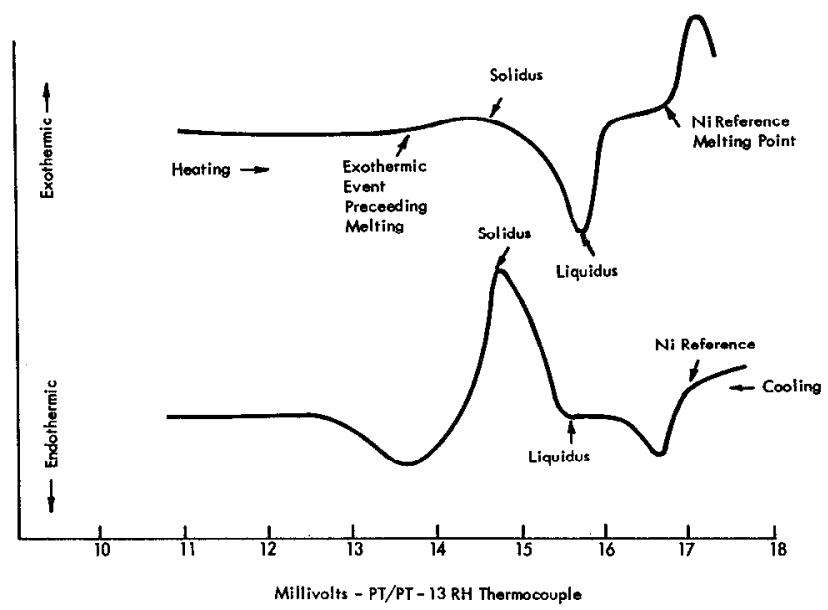

Fig. 3. Typical DTA thermogram for Ni-10Co-9Cr-9W-5.5A1-3.5Ta-1.5Mo-1.5Ti 
Solidus and liquidus temperatures were measured during heating and cooling. The solidus temperature during heating was interpreted as the temperature of tangency between the baseline and the endothermic peak denoting melting. The 1iquidus temperature was interpreted as the endothermic peak inflection temperature. Reverse procedures were used to determine the liquidus and solidus temperatures during cooling. All measured temperatures were calibrated and corrected to the melting point of the unalloyed nickel reference which was assumed to be $1453^{\circ} \mathrm{C}$.

Mechanical test specimens were machined from the disc sections of the integral wheel castings and were tested in stress-rupture at $760^{\circ} \mathrm{C}, 60 \mathrm{~kg} / \mathrm{mm}^{2}$ $\left(1400^{\circ} \mathrm{F}, 85 \mathrm{ksi}\right)$ and $928^{\circ} \mathrm{C}, 30 \mathrm{~kg} / \mathrm{mm}^{2}\left(1700^{\circ} \mathrm{F}, 42 \mathrm{ksi}\right)$. The specimens were carefully machined from the same relative circumferential locations in the castings to minimize possible solidification kinetic effects.

\section{Resu1ts}

\section{Zirconium Effects}

The effects of zirconium were determined at three zirconium levels: nil, $0.07 \%$ and $0.15 \%$ while the boron level was maintained at $0.012 \%$. Solidification range, microporosity and mechanical property measurements at the three zirconium levels are summarized in Table 1.

Zirconium increased the solidification range of the base alloy from $68^{\circ} \mathrm{C}$ without zirconium to $84^{\circ} \mathrm{C}$ at $0.15 \%$ zirconium. The effect of zirconium on $\Delta \mathrm{T}$ was not as great as anticipated from binary phase diagram considerations but was significant, nevertheless. Apparently the solid solubility of zirconium in a highly alloyed nickel-base matrix is at least as great as $0.15 \%$, but its effects on solidus temperatures is considerably less than in unalloyed nicke1.

Zirconium additions increase the microporosity levels in the rim sections of the incegral wheels from $0.20 \%$ without zirconium to $0.50 \%$ at $0.15 \% \mathrm{zir}-$ conium. Zirconium effects were generally consistent with liquid metal pressure considerations; although, the observed increases in microporosity level were generally greater than what the solidification range increases might have otherwise predicted. The number of voids generally increased with zirconium content but the size of the individual voids was unaffected by zirconium content.

Zirconium decreased the $760^{\circ} \mathrm{C}, 60 \mathrm{~kg} / \mathrm{mm}^{2}$ stress-rupture properties in much the same manner as it increased microporosity. The variability between duplicate specimens was much greater with the zirconium additions than with the boron additions. The minimum values, which more appropriately relate to the maximum microporosity measurements, showed a consistent tendency to decrease

Table 1

Effect of Zirconium on $\mathrm{Ni}-10 \mathrm{Co}-9 \mathrm{Cr}-9 \mathrm{~W}-5.5 \mathrm{Al}-3.5 \mathrm{Ta}-1.5 \mathrm{Mo}-1.5 \mathrm{Ti}-.012 \mathrm{~B}$ Integra1 Wheel Castings

\begin{tabular}{l} 
Zireo- \\
nium \\
\hline
\end{tabular}

ni1
$0.07 \%$
$0.15 \%$
Liquidus Solidus

$$
1373^{\circ} \mathrm{C}
$$

$1372^{\circ} \mathrm{C}$

$1372^{\circ} \mathrm{C}$

$1305^{\circ} \mathrm{C}$
$1300^{\circ} \mathrm{C}$
$1288^{\circ} \mathrm{C}$

Micro$\triangle \mathrm{T}$ porosity

$\begin{array}{ll}68^{\circ} \mathrm{C} & 0.20 \% \\ 72^{\circ} \mathrm{C} & 0.36 \% \\ 87^{\circ} \mathrm{C} & 0.50 \%\end{array}$

Stress Ruptu_e Life $760^{\circ} \mathrm{C}, 60 \mathrm{~kg} / \mathrm{mm}^{2} 928^{\circ} \mathrm{C}, 30 \mathrm{~kg} / \mathrm{mm}^{2}$

$\begin{aligned} 105 \text { hours* } & 36 \text { hours } \\ 50 \text { hours* } & 54 \text { hours } \\ 30 \text { hours* } & 49 \text { hours }\end{aligned}$

* Minimum of two tests 
with increasing zirconium content and with higher microporosity levels. However, zirconium semed to have a beneficial effect, if anything, on the $928^{\circ} \mathrm{C}$, $30 \mathrm{~kg} / \mathrm{ms}^{2}$ rupture properties despite its adverse effect on porosity level. This may be due to its influence on the formation of Ta rich discrete MC particles and retardation of grain boundary film formation.

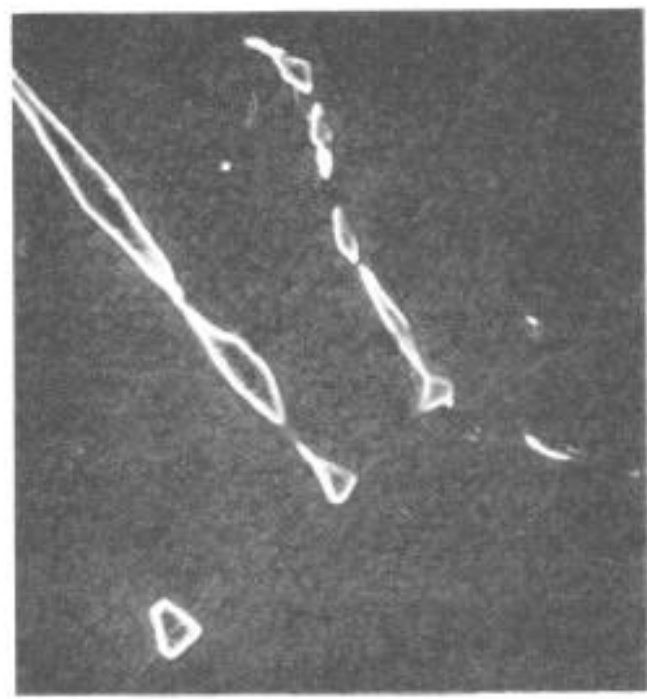

$02 \mathrm{x}, 0.012 \mathrm{~B}$

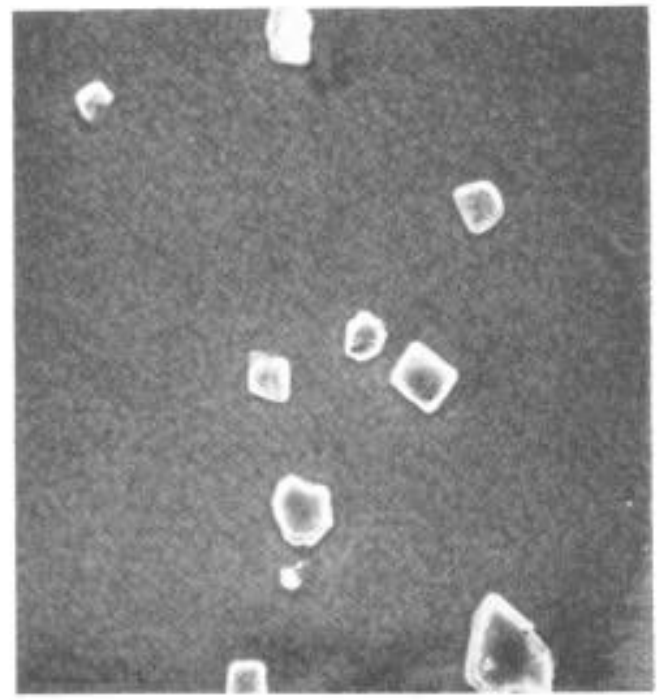

$0.07 \mathrm{Zr}, 0.012 \mathrm{~B}$

$1000 \mathrm{X}$

Fig. 4. Effect of zirconium on primary carbide morphology in $\mathrm{Ni}-10 \mathrm{Co}-9 \mathrm{Cr}-$ $9 \mathrm{~W}-5.5 \mathrm{~A} 1-3.5 \mathrm{Ta}-1.5 \mathrm{Ma}-1.5 \mathrm{Ti}$.

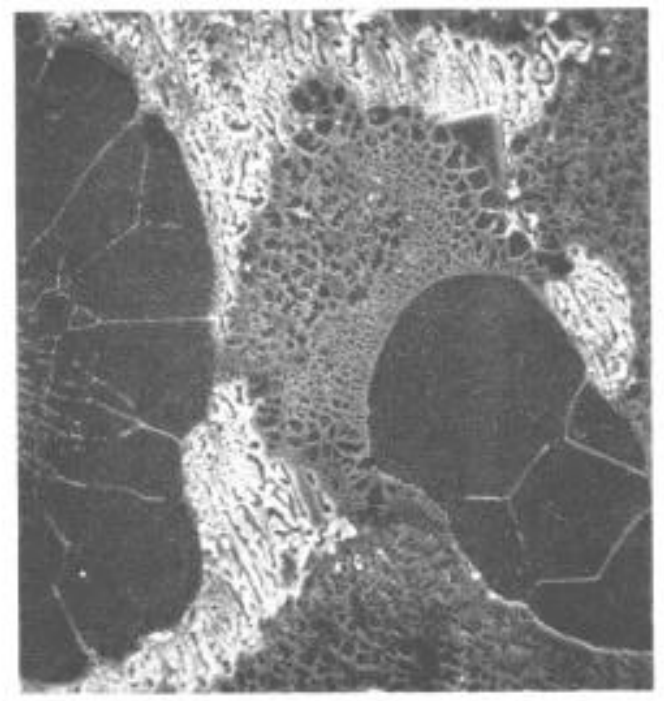

$0.15 \mathrm{Zr}$

$1000 \mathrm{X}$

Fig. 5. Zirconitum-rich segregate in Ni-10Co-9Cr-9W-5.5Al-3.5Ta1. $5 \mathrm{Mo}-1.5 \mathrm{~T} 1$.

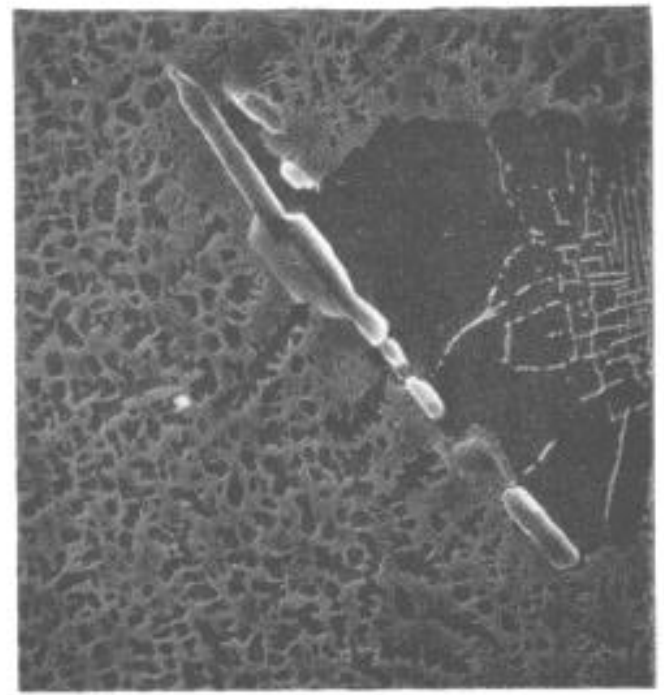

$0.15 \mathrm{Zr}, 0.012 \mathrm{~B}$

$3000 \mathrm{X}$

Fig. 6. Zirconium-rich "stick phase" in Ni-10Co-9Cr-9W5. 5 Al-3. $5 \mathrm{Ta}-1.5 \mathrm{Mo}-1.5 \mathrm{TI}$. 
Zirconium additions had a pronounced effect on the mierostructures in addition to its tendency to promote porosity. First of all, zirconium additions tend to alter the morphology of many of the script-1ike Ta+Ti. MC carbides to a more discrete form, Fig. 4. The discrete. MC contains about half of the titanium found in the script form. Secondly, the addition of zirconium promotes primary $\gamma^{\prime}$ islands - the greater the zirconium, the greater the number and the larger the size of the primary ' ${ }^{\prime}$ islands. Around many of the primary $\gamma^{\prime}$ islands, large areas of a Ni-2r segregation arc present in addition to a boride phase, Fig. 5. Thirdly, the addition of zirconium promotes the formation of a $\mathrm{Zr}$ rich "stick phase" thought to be $\mathrm{Zr}$, $\mathrm{TH}_{2} \mathrm{~S}, \mathrm{C}-\mathrm{Fig}$. 6. Normally, this "stick phase" is found near primary $\gamma^{\prime}$ islands, but high zirconium levela cause this phase to form in the grain boundarfes as well.

When the boron level is increased to $0.025 \%$ at the $0.072 \mathrm{Zr}$ level, the boride phase tends to precipitate out at the grain boundartes in continuous form, Fig. 7. Increasing the $2 \mathrm{r}$ to $0.15 \mathrm{z}$ tends ta suppress this grain boundary reaction.

\section{Boron Effects}

The effects of boron were determined at three boron levels: nil, 0.012z. and $0.025 \%$ while the zirconium content was held constant at $0.07 \%$. Solidification range, microporosity, and mechanical property measurements at the three boron levels are summarized in Table 2.

Contrary to binary $\mathrm{Ni}-\mathrm{B}$ phase diagram expectations, the boron additions actually decreased the solidification range of the base alloy from $79^{\circ} \mathrm{C}$ to $71^{\circ} \mathrm{C}$. Apparently the solid solubility of boron in a highly alloyed nickelbase matrix is virtually nil or strong zirconium-boron interactions occur at high boron levels.

The effects of boron on microporosity in the rim sections of the integral whee 1 castings are shown in $\mathrm{Fig.} \mathrm{8,} \mathrm{and} \mathrm{they} \mathrm{were} \mathrm{consistent} \mathrm{with} \mathrm{liquid}$ metal pressure considerations in that microporosity decreased fron $0.44 \%$ at

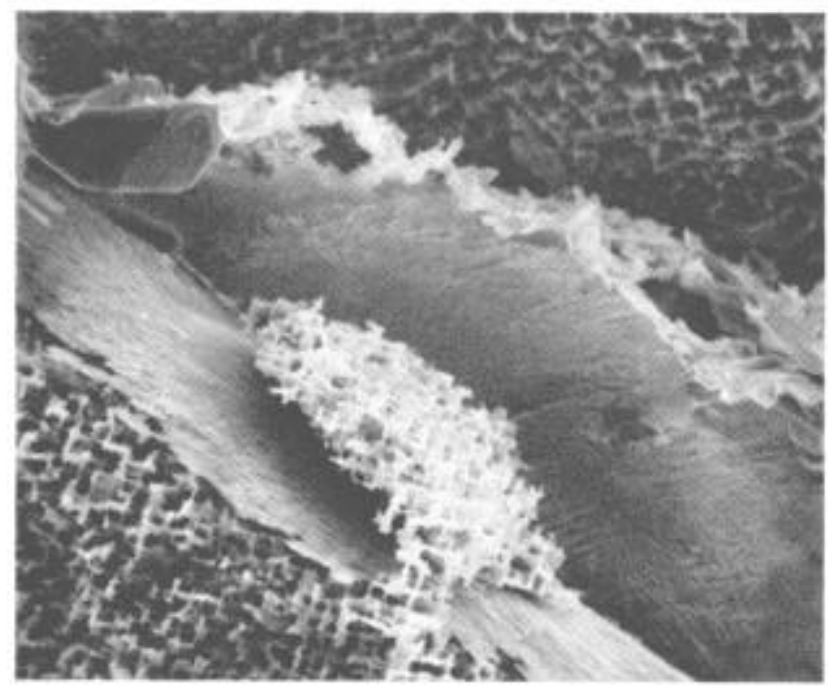

$0.07 \mathrm{Zr}, 0.025 \mathrm{~B}$

$1500 x$

Pig. 7. Continuous boride grain boundary film. 
Table 2

Effect of Boron on $\mathrm{Ni}-10 \mathrm{Co}-9 \mathrm{Cr}-9 \mathrm{~W}-5.5 \mathrm{Al}-3.5 \mathrm{Ta}-1.5 \mathrm{Mo}-1.5 \mathrm{~T} 1-.07 \mathrm{Zr}$ Integral Wheel Castings

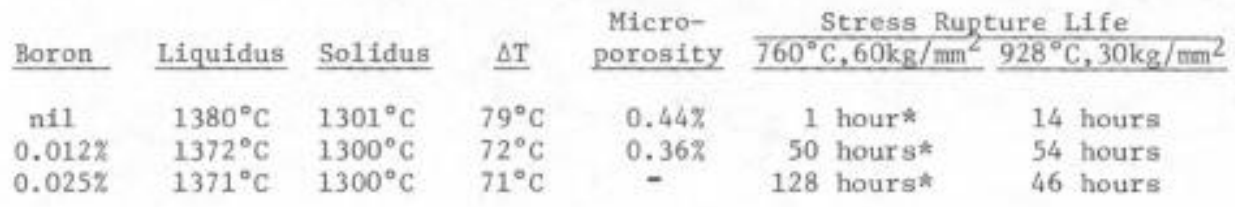

\# Minimum of two tests

$\Delta \mathrm{T}=79^{\circ} \mathrm{C}$ to $0.36 \%$ at $\Delta \mathrm{T}=72^{\circ} \mathrm{C}$. The individual voids tended to be smaller but greater in number as $\Delta \mathrm{T}$ increased.

The effects of boron on the stress-rupture properties of the base alloy were much greater than might have been expected from microporosity considerations alone. The $760^{\circ} \mathrm{C}, 60 \mathrm{~kg} / \mathrm{mm}^{2} \mathrm{ks} 1$ rupture $11 \mathrm{fe}$ increased from 1 hour without boron to 138 hours at $0.025 \%$ boron, while the $928^{\circ} \mathrm{C}, 30 \mathrm{~kg} / \mathrm{mm}^{2}$ rupture iffe increased from 14 hours without boron to 54 hours at $0.012 \%$ boron. These solute effects on mechanical properties are clearly significant and mandate the addition of trace amounts of boron to nickel-base superalloys regardless of solidification range or microporosity considerations.

In the absence of boron, a fine precipitation at the grain boundary is the MC phase. When boron is added, the majority of the fine grain boundary precipitates are an $\mathrm{M}_{3} \mathrm{~B}_{2}$ boride phase. At the $0.012 \%$ B level, large borides are found around prinary $\gamma^{\prime}$ islands. As the boron is increased to $0.025 \%$, the borides change from the normal script shape to more massive form and the majority of the boride that forms in the boundaries tends to be continuous in nature. The addition of $0.15 \% \mathrm{Zr}$ suppresses the amount and morphology of the grain boundary boride phase.

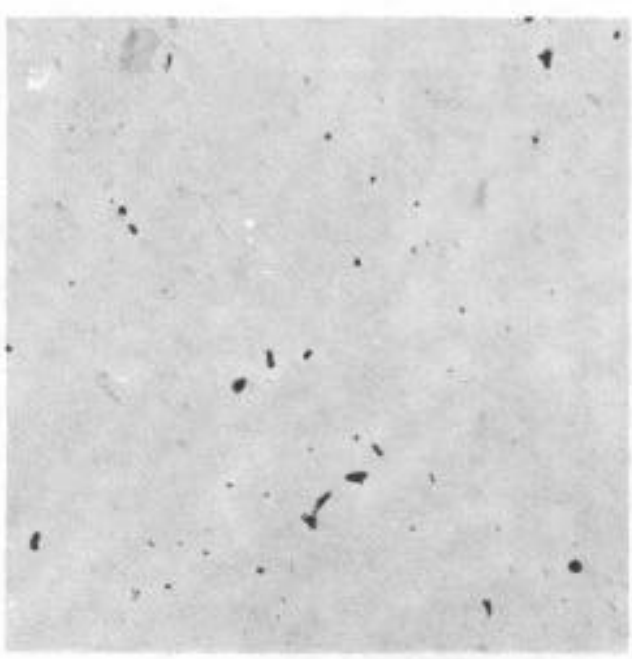

$\mathrm{nil} \mathrm{B}, 0.072 \mathrm{r}$
$0.44 \%$ voids

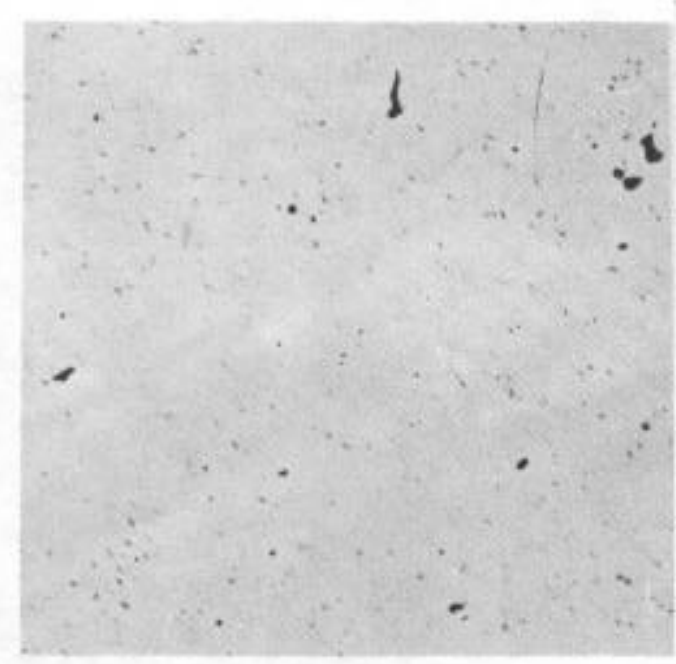

$0.012 \mathrm{~B}, 0.07 \mathrm{Zr}$

$0.36 \%$ voids

Fig. 8. Maximum microporosity in the rin section at various boron levels. 
The massive boride phase contains high $\mathrm{Cr}$ with lesser amounts of Mo $+W$. The finer boride phase forming with the $\mathrm{Zr}$ rich segregation appears to be even more heavily enriched in $\mathrm{Cr}$.

The relative1y constant solidus temperatures coupled with decreasing liquidus temperatures suggest that the boride phases are precipitating directly from the liquid phase during the latter stages of solidification.

\section{Discussion}

It has been concluded from basic fluid flow and heat transfer considerations that the propensity to form microvoids in a casting increases with the square of the solidification range of the alloy being cast. The experimental data obtained from large nickel-base superalloy investment castings used in this study generally support this conclusion. Graphic correlations between microporosity and alloy solidification range, such as the log-log correlation illustrated in Fig. 9, show considerable scatter but agree reasonably we11 with a square relationship with minimum microporosity levels being achieved in alloys with minimum solidification ranges. From binary phase diagram considerations it was hypothesized that significant changes or reductions in the solidification range of nickel-base superalloys might be achieved by simply lowering boron and zirconium at the trace addition level.(i.e. <.01\%). The results of this study reasonably substantiate this hypothesis in the case of zirconium. Boron significantly affected the solidification range of nickel-base superalloys but in a manner quite opposite from that anticipated. In effect, trace additions of bocon reduced the solidification range while trace additions of zirconium increased the solidification range. These opposing effects are probably related to the manner with which these trace solutes partition and precipitate during solidification.

Many highly alloyed nickel-base superalloys precipitate primary $\gamma^{\prime}$ directly from the liquid during solidification. The solidus temperacure of such alloys corresponds to the $\gamma$-prinary $\gamma^{\prime}$ eutectic temperature. Zirconium lowers the solidus temperature of highly alloyed nickel-base superalloys but does so in a manner different from that expected from simple binary phase diagram considerations. Apparently zirconium lowers the $\gamma$-primary $\gamma^{\prime}$ eutectic temperature rather than the solidus temperature per se. Detailed metallographic analyses conclusively show that zirconium preferentially partitions

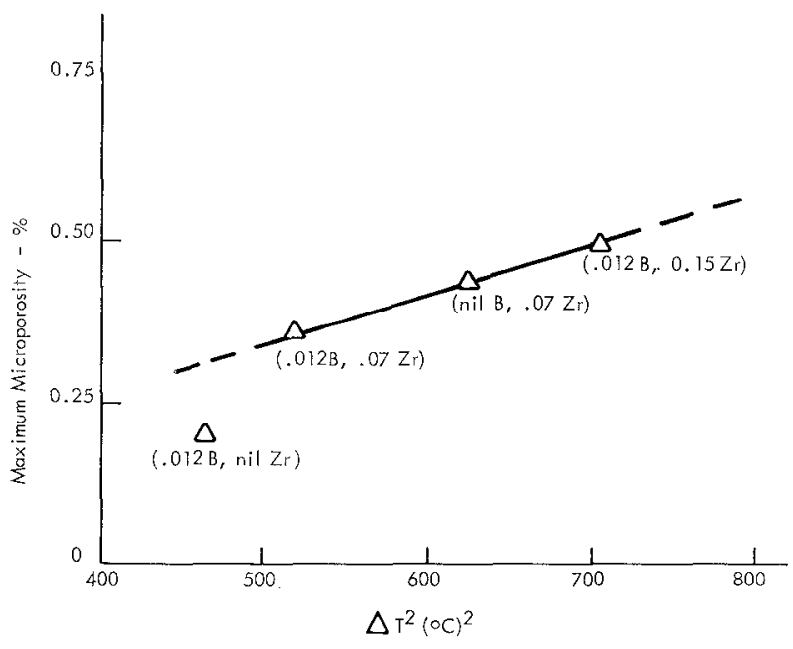

Fig. 9. Graphic correlation between microporosity and solidification range. 
from the primary $\gamma^{\prime}$ structures as they form and forms an Ni-Zr intermetallic phase. Such zirconium rich areas, upon a high temperature heat treatment, will react to form $\mathrm{ZrC}$ and holes. This phenomena has been observed in less highly alloyed superalloys.

Trace amounts of boron additions up to $0.012 \%$ combine with $\mathrm{Cr}$, $\mathrm{W}$, and Mo to form discrete borides in the matrix and in the grain boundaries. Additions up to $0.025 \%$ boron promotes continuous grain-boundary borides during solidification. The temperature(s) at which these boride particles precipitate is not at all certain. However, the morphology and location of the borides coupled with the observed liquidus depression suggest that the boride phase is precipitating directly from the enriched liquid during the latter stages of solidification. Apparently boron is moderately soluble in the liquid phase and depresses the liquidus temperature accordingly. Boron precipi-

- tates in advance of eutectic solidification and has a nil effect on the solidus temperature.

Boron and zirconium are routinely added to cast nickel-base superalloys as it has been shown that trace amounts enhance the creep-rupture properties of nickel-base superalloys. (7) The stress-rupture properties measured in the present investigation verify the criticality of boron to the stress-rupture properties and suggests still another advantage of trace boron additionsreduction in microporosity. The detrimental effects of zirconium on increased porosity and microsegregation as found in this study seriously challenges the traditional additions of zirconium to highly alloyed cast nickel-base superalloys.

The present interest in HIPing of castings to close the porosity formed during solidification indicates the relative importance of mechanical properties and porosity. Minimizing the amount of porosity and microsegregation should allow lower HLP temperatures and shorter HIP times to produce sound castings.

\section{Acknow1edgment}

The authors would like to thank Mr. Robert Mrdjenovich of the Ford Motor Company for supplying the samples used in this study.

\section{References}

1. R. Mehrabian, M. Keane, M. C. Flemings, "Interdendritic Fluid Flow and Macrosegregation; Influence of Gravity," Metallurgical Transactions, 1970, Vol. 1, p. 1209.

2. R. L. Coble, M. C. Flemings, "On the Removal of Pores from Castings by Sintering," Metallurgical Transactions, 1971, Vo1. 2, p. 409.

3. T. S. Piwonka, "New Theories of Solidification," Foundry, June 1972, p. 60.

4. High Temperature, High Strength Nickel Base Alloys, International Nickel Company, Inc., June 1968.

5. Aerospace Structural Materials Handbook, Belfour Stulen, Inc., 1972.

6. P. M. Hansen, Constitution of Binary Alloys, McGraw Hill Book Co., Inc. New York 1958 .

7. R. F. Decker, J. P. Rowe, J. W. Freeman, "Relationship of High Temperature Properties of a Ti + Al Hardened Nickel-Base Alloy to Contamination by Crucibles, Trans. AIME, 1958, Vo1. 212, p. 686. 